\title{
CLIMACUS V BREVIARIUM NOTATUM STRIGONIENSE IN GREGORIJANSKA MODALNOST
}

\author{
JURIJ SNOJ \\ Znanstvenoraziskovalni center SAZU, Ljubljana
}

Izvleček: V Breviarium notatum Strigoniense (kompiliranim konec 13. stol. v Esztergomu) se pojavljata dve obliki climacusa: običajno je prvi ton znaka zapisan z dvojnim punctumom, mestoma pa se pojavlja tudi oblika, kjer je prvi ton znaka podan le z enim punctumom. Oba znaka nastopata bodisi samostojno bodisi kot sestavina širših sestavljenih znakov. Climacus $z$ dvojnim punctumom nastopa zlasti na ključnih tonih modusov; na teh tonih se pojavlja tudi climacus z enojnim punctumom, vendar ne tako izrazito. Iz tega je mogoče sklepati, da je prvi ton climacusa $z$ dvojnim punctumom podaljšan oz. na neki način poudarjen, in da je med obema oblikama znaka rahel pomenski razloček. Vendar se zdi, da pisec pri razločevanje dveh oblik znaka ni bil dosleden; znakz dvojnim punctumom je uporabljal tudi za zapis običajnega postopa treh ali več tonov $v$ smeri navzdol.

Ključne besede: nevmatska notacija, madžarska notacija, gregorijanska modalnost
Abstract: There are two forms of climacus in the Breviarium notatum Strigoniense (compiled at the end of the 13th century in Esztergom): normally, the first note of the sign is given by way of a double punctum, but sporadically there appears also a form in which instead of two puncta there is just one. Both varieties function as independent signs as well as constituent parts of the compound neumes. The climacus with the double first note is found especially on the pivotal notes of the modes; this applies to the climacus with the single first note as well, yet not to the same extent. From this observation it follows that there is a slight distinction between the signs, and that in the double-first-note climacus the first note might be prolonged or emphasised in some other way. However, it seems that the distinction was not strictly observed by the scribe, who used the form with the double punctum also for simple downward motion, without any prolongation of the first note.

Keywords: neumatic notation, Hungarian notation, Gregorian modality

\section{Uvod}

Eno od vprašanj, ki se zastavlja v zvezi z različnimi tipi nevmatskih pisav, kot tudi v zvezi z vsako glasbeno pisavo, je razmerje med zapisom in zapisanim. Na zgolj teoretični ravni predpostavlja to vprašanje obstoj dvojega: obstoj zapisa in obstoj zapisane stvari, pri čemer se med enim in drugim nujno vzpostavlja takšno ali drugačno razmerje. Razmišljanje o razmerju med zapisom in zapisanim se včasih težko izogne nevarnosti, 
da bi potekalo v zaprtem krogu, še zlasti ko gre za stvar, ki jo je mogoče poznati le iz zapisa. To, da je nekaj spoznavno le v krogu in mejah lastnega zapisa, pomeni izenačitev zapisa in njegove vsebine, s tem pa tudi izenačitev razmerja med obema. Vendar je pri dejanskem zgodovinskem in glasbenopaleografskem študiju, kot je študij srednjeveških nevmatskih pisav, drugače: Vednost o srednjeveškem koralu ne izhaja iz enega samega zapisa, pač pa iz nepregledno velike množice rokopisov. Ti z ozirom na način, sistem zapisovanja, tip glasbene pisave, se pravi po svojih pisnih, paleografskih lastnostih niso povsem enaki, čeprav se nanašajo na isto ali vsaj istovrstno glasbo. To pomeni: na osnovi številnih, med sabo različnih zapisov istega (istovrstne glasbe, istih glasbenih celot, spevov) si je mogoče ustvariti tako splošno predstavo o srednjeveškem koralu, kot tudi splošno predstavo o dejanski podobi posameznih spevov. Prav to pa omogoča razmislek o razmerju med zapisom in zapisanim. Katero koli srednjeveško glasbeno pisavo, kateri koli tip nevmatske pisave je mogoče primerjati s splošno predstavo o glasbi, srednjeveškem koralu, zapisanem z njo. Podobno je na ravni posamičnega možno katerikoli dejanski zapis katerega koli speva primerjati s splošno predstavo o njegovi podobi, kot jo je mogoče razbrati iz drugih zapisov. Vprašanje razmerja med zapisom in zapisanim ima tako na ravni stvarnega glasbenopaleografskega študija naslednjo obliko: kako se v danem zapisu - ali v skupini danih zapisov - kaže glasba, kot je poznana na osnovi številnih drugih zapisov; kakšno je razmerje med izbranim zapisom in splošno podobo tistega, kar je zapisano z njim.

Razmerje med zapisom in zapisanim se vzpostavlja z ozirom na različne vidike ali lastnosti zapisanega in ena od teh je tonski sestav gregorijanskih spevov: to, da sestojijo iz niza tonov. Nedvomno so osnovno gradivo srednjeveškega korala kot glasbe toni strednjeveškega tonskega sistema. Toni, ki sami po sebi sicer še nimajo glasbenega smisla, sestavljajo v gregorijanskih spevih nekajtonske glasbene postope, figure, ki nosijo glasbeni smisel, kot jim ga daje podoba speva kot glasbene celote. Čeprav glasbeni toni sami še niso nosilci smisla, vzpostavljajo nevmatske pisave razviden in določljiv odnos do tonov. Iz večine nevmatskih znakov je namreč na neki način razvidno, koliko tonov zaznamujejo, kot tudi kakšno glasbeno gibanje se prek njih vzpostavlja. Omenjeno lastnost nevmatskih pisav je mogoče ilustrirati na primeru nemških nevm: tractulus zaznamuje en ton (gl. ponazorilo 1), prav tako virga (gl. ponazorilo 2), in tako tractulus kot virga obsegata le eno grafično sestavino. Podatus označuje dva tona v smeri navzgor (gl. ponazorilo 3), torculus tri v razmerju nizko-više-niže (gl. ponazorilo 4), torculus resupinus štiri v razmerju nizkoviše-niže-više (gl. ponazorilo 5), torculus resupinus subbipunctis šest v razmerju nizkoviše-niže-više-niže-niže (gl. ponazorilo 6); če primerjamo navedene vsebine z ustreznimi znaki, moremo videti, da je iz znakov razvidna smer gibanja, ki se vzpostavlja prek tonov, prav tako pa je iz vsakega znaka jasno razvidno tudi število zapisanih tonov. Enako je pri drugih nevmatskih znakih: Clivis označuje dva tona v smeri navzdol (gl. ponazorilo 7), porrectus tri v razmerju visoko-niže-više (gl. ponazorilo 8), porrectus subbipunctis pet v razmerju visoko-niže-više-niže-niže (gl. ponazorilo 9) itd. Kot omenjeno, se v vseh teh primerih vzpostavlja razločno razmerje med grafičnimi sestavinami znakov in številom tonov, in sicer tako, da ima vsak ton ustrezno grafično sestavino. 


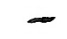

Ponazorilo 1<smiles>[CH]CC</smiles>

Ponazorilo 4<smiles>CCCC</smiles>

Ponazorilo 7

$$
\text { I }
$$

Ponazorilo 2

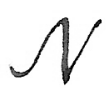

Ponazorilo 5

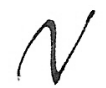

Ponazorilo 8

$$
\int
$$

Ponazorilo 3

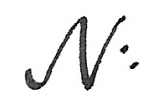

Ponazorilo 6<smiles>C=CCCC</smiles>

Ponazorilo 9

Tudi likvescentni in posebni nevmatski znaki odsevajo število zapisanih tonov. Cephalicus zaznamuje dva tona navzdol, od katerih je drugi likvescentni ton, in znak, ki je ustrezno modificirani clivis, vključuje dva grafična elementa (gl. ponazorilo 10); epiphonus označuje dva tona v smeri navzgor, od katerih je drugi likvescentni in v ustrezno modificiranem podatusu, imenovanem epiphonus, je mogoče prepoznati dve sestavini (gl. ponazorilo 11); virga strata označuje dva tona (gl. ponazorilo 12), pes stratus tri tone (gl. ponazorilo 13), pes quassus dva tona (gl. ponazorilo 14), strophici dva, tri ali več zaporednih tonov na isti višini (gl. ponazorili 15 in 16). Kot je razvidno iz grafičnih podob, ima pri navedenih znakih vsak ton svoje pisno vzporedje.

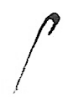

Ponazorilo 10<smiles>CCC</smiles>

Ponazorilo 13

2)1

Ponazorilo 16

$$
\checkmark
$$

Ponazorilo 11

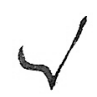

Ponazorilo 14

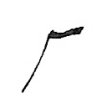

Ponazorilo 12

1)

Ponazorilo 15 
Vendar ni vedno tako, saj nekateri likvescentni in posebni nevmatski znaki ne vzpostavljajo razločnega enosmernega razmerja do zapisanih tonov. Med likvescentnimi je takšen ancus (gl. ponazorilo 17), ki označuje tri tone v smeri navzdol, od katerih sta drugi in tretji likvescentna. Kot je razvidno iz grafične podobe znaka, sta drugi in tretji ton podana $\mathrm{z}$ nečlenjeno krivuljo, ki je ni mogoče razdeliti v dve sestavini. Dvom se vzbuja pri znaku pressus minor, različi znaka pressus maior. Slednji označuje tri tone: dva na isti višini ter nižji ton, kar vse je razvidno iz oblike znaka (gl. ponazorilo 18). V nasprotju s tem označuje pressus minor le dva tona, višjega in nižjega, pri čemer je prvi ton na isti višini kot zadnji ton predhodnega znaka (gl. ponazorilo 19). Pressus minor se prav zaradi tega, ker je njegov prvi ton na isti višini kot predhodni ton, grafično povezuje s predhodnim znakom, ki je največkrat clivis (tako tudi v ponazorilu 19). Če si ogledamo grafično podobo znaka pressus minor, ni povsem jasno, ali sestoji le iz dveh sestavin, od katerih bi vsaka označevala en ton, ali iz treh. Še zlasti pa je povezava med mišljenimi toni in grafično podobo znaka pretrgana pri quilismi oz. znakovnih kombinacijah s quilismo. Quilisma-pes (gl. ponazorilo 20) označuje le dva tona v smeri navzgor, čeravno bi zavojčki nakazovali, da je tonov več; podobno je pri kombinaciji s tractulusom, ki označuje tri tone v smeri navzgor (gl. ponazorilo 21): očitno je srednji med njimi podan z zavojčki, ki bi sami zase z ozirom na svojo grafično obliko nakazovali več kot en sam ton.

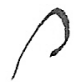

Ponazorilo 17

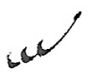

Ponazorilo 20

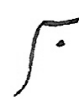

Ponazorilo 18

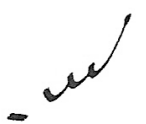

Ponazorilo 21

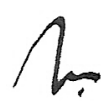

Ponazorilo 19

Predstavljeno bi bilo s pojmovanji semiotične teorije možno izraziti kot vprašanje, ali so nevmatske pisave ikonske ali simbolne, ${ }^{1}$ se pravi, ali so njihovi znaki na neki način grafično oblikovane slike tistega, kar zapisujejo, pri čemer je mogoče vzpostaviti zvezo med zapisom in zapisanim, ali le simboli z dogovorjenim pomenom. Že iz doslejšnjega prikaza je razvidno, da so nevmatske pisave $\mathrm{v}$ nekaterih pogledih ikonske, $\mathrm{v}$ nekaterih simbolne, v nekaterih pogledih pa tako ikonske kot simbolne. Če se osredotočimo na vprašanje, kakšne so v razmerju do najosnovnejšega glasbenega gradiva, tonov samih po sebi, moremo reči, da so prvenstveno ikonske, mestoma pa tudi simbolne: večina znakov ima namreč takšno grafično obliko, da je iz nje jasno razvidno, koliko tonov označujejo; $\mathrm{v}$ nekaterih primerih pa so nevmatski znaki v razmerju do zapisanih tonov vendarle simbolni: tak je npr. ancus in takšni so tudi vsi znaki s quilismo.

1 Pierre Guiraud, Semiology, London, Routledge, 1975, str. 25-27. 


\section{Problem}

V prikazani problemski sklop sodi tudi vprašanje, kaj natančno označuje tipična in prevladujoča oblika znaka climacus (označujočega tri ali več tonov smeri navzdol) v izbranem rokopisu, in sicer v Breviarium notatum Strigoniense (v nadaljevanju BNS). Kot pove že ime, pod katerim je bil izdan, ${ }^{2}$ je rokopis po svojem tipu notirani brevir, se pravi, da vsebuje oficijski proprij za celotno liturgično leto: tako govorjena oz. recitirana besedila (lekcije) kot tudi peta, ki so opremljena z glasbenim zapisom. Ker vsebuje celotno oficijsko liturgijo leta, obsega BNS v današnji podobi 328 folijev. ${ }^{3}$ Po dosedanjem vedenju naj bi bil rokopis nastal v poznem 13. stol. v madžarskem srednjeveškem verskem središču Esztergom (lat. Strigonium). ${ }^{4}$ Pisan je v esztergomski ali madžarski notaciji in sodi med najpomembnejše spomenike imenovanega tipa pisave. Zgodovina rokopisa, ki se hrani v knjižnici premonstratskega samostana Strahov v Pragi (CZ-Pst, DE. I. 7.), ni povsem pojasnjena. $^{5}$

Madžarska notacija je razmeroma dobro raziskana in poznana: tako v pogledu zgodovinskega razvoja kot tudi v pogledu pisnih značilnosti. ${ }^{6}$ Podobno je razmeroma natančno preučena tudi notacija BNS.7 Kot pri drugih nevmatskih pisavah se vzpostavlja vidna povezava med znaki in zapisanimi toni tudi $\mathrm{v}$ tem rokopisu. $\mathrm{V}$ primerjavi $\mathrm{z}$ adiastematskimi nevmami je omenjena povezava $v$ BNS še poudarjena: glasba je namreč tu zapisana v takrat že več kot poldrugo stoletje starem gvidonjanskem črtovju in nevmatski znaki so na mestih, kjer v črtovju zaznamujejo tone, pogosto odebeljeni. Toni so tako v notacijski sliki posebej izpostavljeni in opazni.

Oglejmo si posamične notacijske znake BNS z ozirom na njihovo razmerje do tonov, osnovnega gradiva zapisanih spevov. En sam ton nad zlogom je zapisan s punctumom (gl. ponazorilo 22), ki je grafično drobna romboidna figura; navadno jo uvaja tanka poševna črtica, nastala, ko se pero dotakne pisne površine. Znak je v grafičnem smislu enostaven, obsega eno samo sestavino, zapisan je z eno samo pisno potezo in označuje en sam ton. Clivis, ki podaja dva tona v smeri navzdol (gl. ponazorilo 23), sestoji iz dveh potez in obsega v grafičnem smislu dve sestavini. Porrectus (gl. ponazorilo 24), ki pomeni tri tone v zaporedju visoko-niže-više, je iz treh sestavin. Podobno je tudi pri drugih znakih: Dva tona navzgor sta zapisana z znakom, podobnim ležečemu S (gl. ponazorilo 25) in prvi od obeh tonov je na mestu spodnje krivulje, drugi pa na mestu zgornje. Torculus (gl. ponazorilo 26) je nadaljevanje podatusa in tretji ton znaka je podan z rahlim odstavnim zavojčkom ob koncu navpične poteze navzdol. Če sledi torculusu še en ton v smeri navzdol, če torej obsega tone v zaporedju: nizko-više-niže-niže, je potezi v smeri navzdol priključena sestavina, ki je grafično enaka clivisu (gl. ponazorilo 27). Vzporedno s tem

2 Breviarium notatum Strigoniense, ur. Janka Szendrei, Musicalia Danubiana 17, Budimpešta, Magyar Tudományos Akadémia Zenetudományi Intézet, 1998.

3 J. Szendrei, nav. delo, str. 41 (Introduction).

${ }^{4}$ Nav. delo, str. 42, 44-45 in op. 19.

5 Nav. delo, str. 40.

6 Janka Szendrei, Die Geschichte der Graner Choralnotation, Studia musicologica XXX (1988), str. 5-234.

7 Breviarium notatum Strigoniense, ur. Janka Szendrei, str. 42-46. 
znakom so trije toni v smeri navzgor (scandicus, gl. ponazorilo 28), zapisani z na neki način prelomljeno krivuljo; znak tako izgleda kot ukrivljeni ali zlomljeni podatus, pri čemer je srednji ton postopa podan prav z levim ukrivkom (ali usločnino). Razširitev opisanega znaka predstavlja scandicus flexus (gl. ponazorilo 29), ki izgleda kot zlomljeni torculus. Iz prikazanega je razvidno, da so znaki BNS sestavljeni tako, da je iz njihove grafične oblike možno razbrati, koliko tonov vsebuje postop, ki ga zaznamujejo. V razmerju do tonov so torej ikonski.

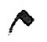

Ponazorilo 22

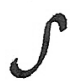

Ponazorilo 25

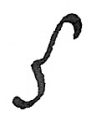

Ponazorilo 28

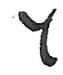

Ponazorilo 23

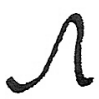

Ponazorilo 26

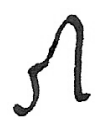

Ponazorilo 29

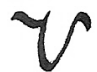

Ponazorilo 24

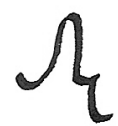

Ponazorilo 27

Močan dvom o ikonskosti pa vzbuja prevladujoča oblika climacusa, ki zaznamuje tri ali več tonov v smeri navzdol, kot tudi tisti sestavljeni znaki, ki kot eno od svojih sestavin vključujejo prevladujočo obliko climacusa. V BNS nastopa climacus v dveh oblikah, od katerih je prva običajna, druga pa skrajno redka. Pri običajni obliki (gl. ponazorilo 30) je zgornji ton postopa zapisan z dvema grafičnima elementoma, dvema punctumoma, ki jima v vertikali sledita dva ali več nadaljnjih punctumov, ki označujejo nadaljnje tone padajočega postopa (v nadaljevanju je ta oblika poimenovana $\mathrm{z}$ izrazom »climacus $\mathrm{z}$ dvojnim nastavkom«.) Drugačna je druga, redkejša oblika climacusa (gl. ponazorilo 31), ki obsega le tri sestavine, in sicer tri v vertikali podpisane punctume, od katerih je prvi opremljen s tanko poševno črtico, nastalo, ko se pero dotakne pisne površine (v nadaljevanju »climacus z enojnim nastavkom«). Kot omenjeno, je climacus z enojnim nastavkom z ozirom na pogostnost pojavljanja izjemen. Opisani obliki se pojavljata tudi v širših, večtonskih sestavljenih kombinacijah, kot je npr. scandicus subbipunctis (gl. ponazorili 32 in 33), climacus resupinus (gl. ponazorili 34 in 35), torculus resupinus subbipunctis (gl. ponazorilo 36 in 37) ipd. Na prvi pogled se zdi, da je climacus z enojnim nastavkom v sestavljenih večtonskih znakih nekoliko bolj pogost, čeprav še vedno dosti redkejša kot climacus z dvojnim nastavkom. 


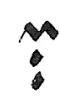

Ponazorilo 30

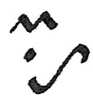

Ponazorilo 34

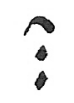

Ponazorilo 31

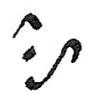

Ponazorilo 35

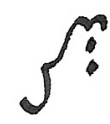

Ponazorilo 32

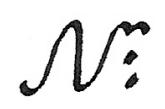

Ponazorilo 36

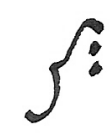

Ponazorilo 33

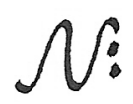

Ponazorilo 37

Glede na to, da so znaki notacije BNS zamišljeni tako, da je iz njih natančno razvidno število tonov, oz. da ima vsak ton $\mathrm{z}$ nevmatskim znakom zapisanega postopa $\mathrm{V}$ samem znaku svojo grafično vzporednico, bi moral imeti prvi ton postopa, zapisanega s climacusom z dvojnim nastavkom, dvojno dolžino, tj. obsegati bi moral dva tona iste višine; nasprotno pa naj bi bili z drugo, redkejšo obliko climacusa (z enojnim nastavkom) zapisani trije ali več po dolžini enakih tonov v smeri navzdol. Vendar bi takšno branje ustreznih mest pomenilo, da je v domala vseh s climacusom zapisanih postopih prvi ton po svoji dolžini poudarjen, podvojen, kar se z ozirom na splošno podobo zapisane glasbe ne zdi verjetno. Kaj torej zaznamuje climacus z dvojnim punctumom? Ga je treba brati na ikonski način in zaznamujeta punctuma dvojno dolžino tona, ali pa je simbol za tri (ali več) po dolžini enakovrednih tonov v smeri navzdol? Če je res slednje, se pojavljajo nadaljnja vprašanja: Zakaj se prvi ton climacusa zapisuje z dvema punctumoma? Zakaj obstojita dve različni obliki znaka, od katerih je druga sicer izjemno redka? Zakaj je v sestavljenih znakih climacus z enojnim punctumom vendarle nekoliko pogostejši?

\section{Metodologija}

Vprašanje, kaj pomeni climacus z dvojnim nastavkom, je bilo že obravnavano, in sicer v sklopu razpravljanja o zgodovini madžarske notacije, kar pomeni, da je bilo v metodološkem smislu obravnavano zlasti na zgodovinski način: Znak naj bi bil v madžarsko notacijo prevzet po nekaterih italijanskih pisavah, kjer ima climacus podobno obliko. Prvotno naj bi imel v madžarski notaciji drugačen pomen kot climacus z enojnim nastavkom, in sicer naj bi njegov dvojni punctum v resnici označeval podaljšani ton. Vendar naj bi se pomen znaka v madžarskih rokopisih menjal že v 13. stol., ko naj bi se začel uporabljati kot običajni in prevladujoči, čeprav ne edini znak za postop treh ali več tonov navzdol. BNS že izkazuje pomenski premik: dvojni nastavek climacusa v tem rokopisu ne označuje več dvojne dolžine, in dva različna climacusa se v tem rokopisu uporabljata le iz pisnotehničnih razlogov. ${ }^{8}$

\footnotetext{
8 Nav. delo, str. 44-45.
} 
Odgovoru na vprašanje o pomenu znaka se je možno približati tudi po drugi, primerjalni poti. Skladno z uvodnim razmislekom bi bilo možno primerjati določeni izbor climacusov v BNS z ustreznimi mesti v drugih, zgodovinsko bližnjih rokopisih, ki bi imeli isto vsebino in iste speve; iz tako izpeljane primerjave bi bilo mogoče razbrati pomen dvom vzbujajočega znaka. Vendar je ob tej zamisli treba upoštevati naslednje: Gregorijanski koral oz. srednjeveška liturgična monodija ni eksaktna glasba v tem smislu, da bi imeli gregorijanski spevi eno samo nujno podobo (kot npr. polifone skladbe 16. stol.). Kot je znano, obstojijo gregorijanski spevi v bolj ali manj številnih variantah, nastalih ob prostorskem širjenju repertoarja skozi čas; posamični rokopisi (ali ožje povezane skupine rokopisov) imajo tako lahko lastne, unikatne variante. Prav to pa relativizira opisano primerjalno metodo. Climacus z dvojnim nastavkom lahko zaznamuje unikatne variante, kar pomeni, da primerjava ustreznih mest $\mathrm{z}$ drugimi rokopisi ne more biti povsem zanesljivo vodilo pri določanju pomena znaka. Poleg tega izhaja iz dejstva, da gregorijanski spevi niso eksaktna glasba, še en pomislek: Neeksaktnost same glasbe dopušča tudi neeksaktnost in ohlapnost zapisa. Isti spev, ista standardna fraza ali ista standardna figura se v istem rokopisu lahko pojavlja v dveh ali celo več glasbenih variantah. Če je možna tovrstna ohlapnost v glasbi, če je možno, da se ista glasba (isti spev, ista figura) pojavlja v istem rokopisu v dveh variantah, je možno tudi to, da je ista glasba ali isti glasbeni postop v istem rokopisu zapisan na dva različna načina. To pomeni, da ima isti znak v istem rokopisu lahko dva variantna pomena, kot tudi, da imata dva malenkostno različna znaka $\mathrm{v}$ istem rokopisu lahko isti pomen. Za ilustracijo slednjega naj bo naveden zapis responzorija Ecce iam v BNS:9 Ko je ob koncu speva zapisan incipit tistega dela responzorija, ki naj se ponovi (repetenda), je zapis nekoliko drugačen; znotraj samega responzorija je na ustreznem mestu climacus z dvojnim nastavkom, v repetendi pa climacus z enojnim nastavkom (gl. ponazorili 38 in 39). Očitno imata dva malenkostno različna znaka tu isti pomen. Iz prikazanega je mogoče povzeti: Ker gregorijanski koral sam ni eksaktna glasba, odgovora na zastavljeno vprašanje ni mogoče poiskati po deduktivni poti. Pokaže ali nakazuje ga lahko le raziskovalna empirija. Prav zato pa je empirični tudi odgovor; bolj kot da bi bil dokončen, nakazuje smer rešitve, in bolj kot da bi bil izključevalen, dopušča približke in takšna ali drugačna odstopanja. Z ozirom na to je zastavljeno vprašanje, kaj pomeni climacus z dvojnim nastavkom v BNS, potrebno nekoliko prilagoditi in razostriti: Kam vodi in kaj pokaže primerjava mest, kjer se v BNS pojavlja climacus, z ustreznimi mesti v drugih virih?

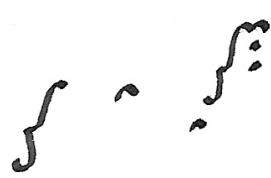

Ponazorilo 38

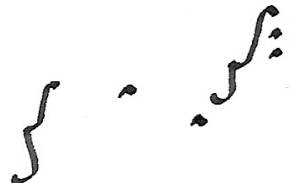

Ponazorilo 39

Za natančnejši pregled je bilo izbrano 17 responzorijev z začetka rokopisa, kar pomeni iz adventnega obdobja. ${ }^{10}$ Kot je znano, sodijo adventni responzoriji v najstarejši in zato

9 Fol. 6r.

${ }^{10}$ Izbrani so bili naslednji responzoriji: I. modus: Canite tuba (BNS 4r, IA 10r), Descendit de 
tudi bolj ustaljeni gregorijanski repertoar. Pregledana in izpisana so bila vsa mesta, kjer se v izbranih responzorijih pojavlja climacus, in sicer bodisi kot samostojno znamenje bodisi kot sestavina širšega, več kot tritonskega znaka. Vsa ta mesta so bila v smislu osnovne orientacije primerjana $\mathrm{z}$ drugim, isto vsebino vključujočim rokopisom. Izbran je bil »Istanbulski antifonal « (v nadaljevanju IA), imenovan tako, ker je zdaj v Istanbulu. ${ }^{11}$ Ta rokopis je nastal nekaj desetletij kasneje kot BNS, okoli leta 1360, in sicer v neki ne natančneje določeni škofiji esztergomske metropolije. V Istanbul naj bi bil odnesen na začetku 16. stol. ${ }^{12}$

IA je pisan v istem tipu pisave kot BNS. Notacijski znaki rokopisa imajo grafično enako ali zelo podobno obliko kot znaki BNS in tudi pisna tehnika mlajšega rokopisa se zdi bolj ali manj enaka pisni tehniki starejšega. Pisavi obeh virov se tako razlikujeta zlasti po tem, da izkazuje notacija IA mlajšo pisnorazvojno stopnjo. Rokopisa sta si zgodovinsko nedvomno zelo blizu; a kot se v starejšem skoraj vedno pojavlja le climacus z dvojnim nastavkom, je v mlajšem z morebitnimi zelo redkimi izjemami to znamenje odsotno. Prvi ton climacusa je v IA zapisan s punctumom, ki ga uvaja poševna črtica (gl. ponazorilo 40), zapisana $v$ grafičnotehničnem smislu podobno kot punctum (in prvi od obeh punctumov v climacusu z dvojnim nastavkom) v BNS. Podobno je tudi pri sestavljenih znakih; trije ali več tonov v smeri navzdol so v sestavljenih znakih zapisani v IA z vertikalno podpisanimi punctumi, pri čemer je prvi med njimi (sicer sredi znaka) podan le z eno grafično sestavino, iz česar je jasno razvidno, da gotovo nima dvojne dolžine (gl. ponazorilo 41). Ker sta si rokopisa močno sorodna, bi bilo že iz te razlike mogoče soditi, da prvi ton climacusa v BNS nima dvojne dolžine. A oglejmo si, kaj je mogoče izpeljati iz primerjalne obravnave izbranih primerov.

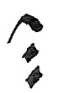

Ponazorilo 40

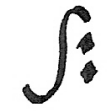

Ponazorilo 41

caelis (brez prozul, BNS 15r, IA 19v); II. modus: Non auferetur (BNS 5r, IA 10v), Docebit vos (BNS 9v, IA 8v); III. modus: Egredietur dominus (BNS 10r, IA 13r), Me oportet minui (BNS 7r, IA 10v); IV. modus: Videbunt gentes (BNS 10v, IA 13v, tu »Viderunt gentes«); V. modus: Ecce iam veniet (BNS 6r, IA 10v); VI. modus: Modo veniet (BNS 9r, IA 12r), Clama in fortitudine (BNS 8v, IA 12r); VII. modus: Vicesima quarta (BNS 4v, IA 10r), Nascetur nobis (BNS 8r, IA 11r), Praecursor pro nobis (BNS 10v, IA 13r); VIII. modus: Non discedimus (BNS 9v, IA 11r), Orietur stella (BNS 8v, IA 12r), Virgo Israel (BNS 7r, IA 10v), Iuravi dicit (BNS 5r, IA 11r).

${ }^{11}$ Istanbul, Topkapi Sarayi Müzesi, Deissmann 42. Rokopis je dostopen v faksimilu: The Istanbul Antiphonal - about 1360, ur. Janka Szendrei, Musicalia Danubiana 18, Budimpešta, Magyar Tudományos Akadémia Zenetudományi Intézet, 2002.

12 Janka Szendrei, Mittelalterliche Choralhandschriften in Istanbul, Cantus Planus. Papers Read at the 9th Meeting, Esztergom and Visegrád, 1998, ur. László Dobszay, Budapest, Hungarian Academy of Sciences, 2001, str. 75-77. 


\section{Obravnava gradiva}

Vseh primerov samostojnega climacusa $\mathrm{z}$ dvojnim nastavkom je v izbranih responzorijih 30 (gl. tabelo 1); enojni climacus se pojavi osemkrat. Na vseh teh mestih se z izjemo 10 nedoločljivih mest (melodična varianta, druga melodija oz. melodični obrazec v verzu) pojavlja v IA climacus z enojnim nastavkom. Pri climacusih, ki nastopajo kot sestavina drugih znakov, je razmerje med znamenji z enojnim in dvojnim nastavkom spremenjeno v prid enojnega nastavka: v izbranih responzorijih je v BNS 78 primerov sestavljenih znakov z enojnim climacusom in 42 primerov takšnih sestavljenih znakov, ki vključujejo climacus z dvojnim nastavkom. Tudi na teh mestih - z izjemo pet nedoločljivih ${ }^{13}-$ je v IA ustrezni ton zapisan z eno samo grafično sestavino, ki lahko označuje le en sam ton.

\section{Tabela 1}

Climacusi v adventnih responzorijih

\begin{tabular}{|l|l|}
\hline Climacus & \multicolumn{2}{l|}{ Število primerov } \\
\hline z dvojnim nastavkom & 30 \\
\hline -kot samostojno znamenje & 42 \\
\hline -v kombinacijah & 4 \\
\hline z enojnim nastavkom & 8 \\
\hline -kot samostojno znamenje & 78 \\
\hline -v kombinacijah &
\end{tabular}

Ob teh številkah je treba omeniti, da je določevanje, kaj je samostojni climacus, kaj ne, kaj climacus z enojnim nastavkom in kaj z dvojnim, mestoma dvomno. V nekaterih primerih ni jasno, ali je climacus - bodisi z enojnim ali z dvojnim nastavkom - samostojno znamenje ali pa ga je treba razumeti kot nadaljevanje predhodnega znaka, s katerim bi tvoril pisnovsebinsko enoto. Pri dvojnem climacusu se je mogoče opreti na to, ali se dvojni punctum stika s predhodno grafično sestavino ali ne; vendar sta stik ali odsotnost stika lahko le slučajna, kar pomeni, da vprašanja ni mogoče dokončno rešiti. Kljub temu je bilo pri obravnavi in razvrščanju primerov uporabljeno merilo stičnosti: stični climacusi z dvojnim prvim tonom so bili razumljeni kot sestavina sestavljenega znaka, nestični pa kot primeri samostojnega climacusa. Pri enojnem climacusu je vprašanje še nekoliko bolj zapleteno. V izbranem gradivu se pojavi ta znak na začetku zloga (kar pomeni, da ima gotovo vlogo samostojnega znaka) le enkrat (re. Docebit), v vseh drugih primerih pa nastopa climacus z enojnim nastavkom sredi melizma, in sicer tako, da bi ga bilo mogoče razumeti tudi kot nadaljevalno širjenje predhodnega znaka. Za ilustracijo naj bo navedeno zaporedje podatusa subbipunctis in climacusa (gl. ponazorilo 42), zaporedje, ki bi ga bilo

${ }^{13}$ Med nedoločljiva je šteto tudi mesto na začetku responzorija Videbunt gentes (nad zlogom tuum), kjer nastopi v IA sestavljeno znamenje, ki bi ga bilo mogoče razumeti kot zvezo petih tonov (nizko-više-niže-niže-niže) ali pa kot spoj torculusa in climacusa, ki bi kot tak obsegal šest tonov (nizko-više-niže-isto-niže-niže). Tudi v IA so nekateri sicer redkejši znaki na podoben način dvoumni kot climacusi v BNS. Pravkar omenjeni sestavljeni znak se pojavlja tudi v BNS, gl. nadaljevanje. 
mogoče razumeti tudi kot eno samo znamenje. Ne glede na nejasnost, so bili tovrstni primeri razumljeni kot samostojni climacus z enojnim punctumom.

\section{$\int$}

\section{Ponazorilo 42}

A tudi vprašanje, ali je v danem primeru zapisan enojni ali dvojni punctum, ni vedno lahko odgovorljivo. Ustrezni del znaka je največkrat oblikovan tako, da je jasno razvidno, ali sestoji iz ene same ali dveh grafičnih sestavin; nekajkrat pa je zapis dvoumen in v ustrezni potezi bi bilo mogoče sprevideti tako eno samo ali pa dve sestavini. V takih primerih je bila pri razvrščanju upoštevana verjetnejša možnost.

Poleg tega so v rokopisu tudi primeri, da je sam znak sicer razločno oblikovan, vendar ni jasno, koliko ton zaznamujočih grafičnih sestavin v resnici vključuje. Takšni so primeri znakov, ki sestojijo iz zaporedja torculusa ali clivisa kot prve sestavine in climacusa kot druge. Da bi bilo mogoče bolje predstaviti problem, si še pred obravnavo omenjenih znakov oglejmo znak, ki bi ga bilo mogoče poimenovati z izrazom torculus flexus. Pri samem torculusu (kot tudi pri clivisu) je zadnji ton podan z zaključno potezo navzdol. Poleg običajnih, tako ali drugače razširjenih torculusov, se pojavlja v BNS tudi znak, ki izgleda kot zveza torculusa in clivisa (znamenje je bilo že omenjeno, gl. ponazorilo 27). Strogo ikonsko branje tega znaka bi navajalo k prepoznanju petih tonov v zaporedju nizko-više-niže-isto-niže; a zelo verjetno zaznamuje ta redki znak le štiri tone (nizkoviše-niže-niže), pri čemer je torculusu (nizko-više-niže) dodan še en nižji ton. Vodoravna črtica, ki bi jo bilo ob ikonskem branju mogoče razumeti kot ponovitev predhodnega tona, se pojavlja v tem znaku zelo verjetno le iz pisnotehničnih razlogov, saj morata biti navpični, dva tona v smeri navzdol zaznamujoči potezi na neki način razmejeni.

Torculus flexus je redek in njegov pomen je razmeroma jasen. Dvom pa se vzbuja pri znakih, kjer se sestavljata torculus ali clivis in climacus (gl. ponazorilo 43). Tudi tu se prva, zgornji ton označujoča sestavina climacusa navezuje na predhodno pokončno črto - zadnji ton torculusa oz. clivisa, pri čemer ni jasno: ali je prva sestavina climacusa le pleonazem za zadnji ton torculusa oz. clivisa (kot v primeru znaka torculus flexus), do katerega bi prišlo le iz pisnotehničnih razlogov, ali pa pomeni prva sestavina climacusa ponovitev predhodnega tona, ki bi bil tako hkrati tudi prvi v sledečem spustu navzdol. V prvem primeru bi kombinacija s torculusom označevala pet tonov (nizko-više-niže-niže-niže), v drugem šest (nizko-više-niže-isto-niže-niže). Ne glede na prikazano nejasnost so ti primeri razumljeni kot primeri climacusa $\mathrm{z}$ enojnim nastavkom $\mathrm{v}$ sestavljenih znakih.

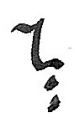

\section{Ponazorilo 43}


Bolj kot da bi obravnava prikazanih vprašanj vodila do veljavnih zaključkov, ponazarja gregorijansko neeksaktnost. Opisanih dilem najbrž ne bi bilo težko rešiti, če bi bila zapisana vsebina sama eksaktna in če bi bila skladno z njo eksaktna tudi pisava. A kot je vsebina sama $v$ nekaterih detajlih nedoločena, tako ostaja nejasna tudi pisava. Izsledke primerjave z IA, ki je nedvomno močno blizu BNS, bi bilo zato mogoče strniti v naslednjo sodbo: Climacus z dvojnim nastavkom, bodisi samostojni bodisi kot sestavina sestavljenega znaka, ima v BNS načeloma isti pomen kot sicer redkejši climacus z enojnim nastavkom. Še točneje bi bilo mogoče reči, da med climacusom z enojnim in dvojnim nastavkom $\mathrm{v}$ tem rokopisu ni eksaktne pomenske razlike. Ob tem se zastavlja vprašanje, zakaj rokopis vendarle uporablja dva različna znaka (oz. dve vrsti znakov). Je možno, da zaznamujeta dva po sestavi različna znaka isto? Odgovor je treba iskati v dejstvu, da gregorijanski koral ni eksaktna glasba. Obstoj dveh climacusov nakazuje razlikovanje, a to ni eksaktno izpeljano. To pomeni: Climacus z dvojnim nastavkom zaznamuje tri tone v smeri navzdol, mestoma pa je bil z njim mišljen morda tudi postop treh (ali več) tonov navzdol s podaljšanim oz. na neki način poudarjenim prvim tonom. V obliki primera si lahko predstavljamo, da je nevmator rokopisa (ali njegove predloge) tri tone navzdol zapisoval običajno s climacusom z dvojnim nastavkom, mestoma pa tudi s climacusom z enojnim nastavkom, slednje zlasti v sestavljenih znakih; če je menil, da mora biti prvi ton podaljšan oz. poudarjen, se je odločil za dvojni nastavek; a mestoma morda ni vedel, ali je prvi ton v postopu navzdol podaljšan ali ne, in temu ustrezno se je odločil bodisi za climacus z enojnim ali dvojnim nastavkom. Posledica tega je opisana nejasnost in kljub splošni razumljivosti zapisa in določenosti zapisane glasbe so v rokopisu tudi neeksaktna mesta.

\section{Climacus in modalnost}

Dejstvo, da se v BNS pojavljata dve vrsti climacusa odpira še en sklop vprašanj, ki zadevajo samo gregorijansko melodiko in njeno modalnost. Climacus zaznamuje spust navzdol, spust, ki poteka največkrat postopno, tj. brez skokov, in obsega tri tone ali več. Izhodišče spusta je zgornji ton climacusa, prav tisti, ki se zapisuje bodisi z enim ali dvema punctumoma, in ta je kot izhodišče spusta v plastični gregorijanski melodiki na neki način poudarjen in izpostavljen. Kot se je pokazalo ob iskanju in pregledovanju climacusov, ti ne nastopajo na vseh tonih enako pogosto (tj. njihov zgornji ton, izhodišče spusta se ne pojavlja na vseh tonih enako pogosto). Natančnejši pregled kaže, da so toni, na katerih se zlasti pogosto pojavljajo climacusi, v različnih modusih različni. S stališča iskanja pomenskega razločka med enojnim in dvojnim climacusom pa je še zlasti zanimivo to, da obstoji z ozirom na pogostnost pojavljanja na določenih tonih danega modusa med climacusom z dvojnim in climacusom z enojnim nastavkom občuten razloček. Z drugimi besedami: $v$ danem modusu se na določenih karakterističnih tonih climacusi z enojnim nastavkom ne pojavljajo $\mathrm{z}$ isto pogostnostjo kot climacusi z dvojnim nastavkom. 


\section{Tabela 2}

Climacusi po modalni pripadnosti spevov

\begin{tabular}{|c|c|c|}
\hline Ton & Dvojni climacus & Enojni climacus \\
\hline \multicolumn{3}{|c|}{ I. modus } \\
\hline $\mathrm{f}$ & 4 & 4 \\
\hline $\mathrm{g}$ & 1 & \\
\hline $\mathrm{a}$ & 6 & \\
\hline $\mathrm{c} 1$ & 5 & 1 \\
\hline \multicolumn{3}{|c|}{ II. modus } \\
\hline $\mathrm{f}$ & 4 & 6 \\
\hline g & & 2 \\
\hline $\mathrm{a}$ & 2 & \\
\hline \multicolumn{3}{|c|}{ III. modus } \\
\hline $\mathrm{g}$ & & 1 \\
\hline $\mathrm{a}$ & 1 & 1 \\
\hline $\mathrm{c} 1$ & 1 & 4 \\
\hline \multicolumn{3}{|c|}{ IV. modus } \\
\hline f & 1 & \\
\hline g & 1 & \\
\hline $\mathrm{a}$ & 3 & 1 \\
\hline \multicolumn{3}{|c|}{ V. modus } \\
\hline $\mathrm{a}$ & 1 & \\
\hline $\mathrm{b}$ & 1 & \\
\hline $\mathrm{c} 1$ & 3 & 1 \\
\hline \multicolumn{3}{|c|}{ VI. modus } \\
\hline $\mathrm{a}$ & & 3 \\
\hline h (b) & 2 & 7 \\
\hline $\mathrm{c} 1$ & & 1 \\
\hline \multicolumn{3}{|c|}{\begin{tabular}{|l} 
VII. modus \\
\end{tabular}} \\
\hline $\mathrm{f}$ & & 5 \\
\hline $\mathrm{g}$ & & 1 \\
\hline $\mathrm{a}$ & & 2 \\
\hline $\mathrm{b}$ & & 1 \\
\hline $\mathrm{c} 1$ & 11 & 9 \\
\hline $\mathrm{d} 1$ & 4 & 2 \\
\hline e1 & 3 & 3 \\
\hline $\mathrm{fl}$ & 6 & 1 \\
\hline g1 & 1 & \\
\hline \multicolumn{3}{|c|}{ VIII. modus } \\
\hline $\mathrm{f}$ & 2 & 3 \\
\hline $\mathrm{a}$ & & 5 \\
\hline $\mathrm{c} 1$ & 10 & 15 \\
\hline $\mathrm{d} 1$ & 2 & 1 \\
\hline
\end{tabular}

V nadaljevanju si oglejmo, na katerih tonih se pojavljajo enojni in dvojni climacusi v posameznih modusih. Pogled v tabelo 2 pokaže, da se dvojni climacus pojavlja v vsakem 
od osmero modusov zlasti na enem, dveh ali treh tonih. V I. modusu so to toni $\mathrm{f}$, a in $\mathrm{cl}$, v II. modusu f in a, v III. modusu a in c1, v IV. modusu a, v V. modusu c1, v VI. modusu b, v VII. modusu c1, d1 in f1, ter v VIII. modusu c1 in d1. Kot je razvidno iz tega naštevka, so med imenovanimi toni tudi tenorski toni modusov (v tabeli podani krepko): toni, ki ustvarjajo v razmerju do finalisa značilno modalno napetost, in okoli katerih se zelo pogosto gibljejo gregorijanske melodije posameznih modusov. V I. modusu je tenorski ton a, v II. modusu f, v III. c1, v IV. modusu a, v V. modusu je tenorski ton c1, v VI. modusu a, v VII. modusu d1 in v VIII. modusu c1. Razhajanje med tonom, na katerem se najpogosteje pojavlja climacus z dvojnim nastavkom in tenorskim tonom je opazno le v VI. in VII. modusu. A tudi ostali toni, na katerih se pogosteje pojavlja climacus z dvojnim nastavkom, so v neki zvezi z modalnostjo. V modalnosti protus (s finalisom d, I. in II. modus) se kot tona, na katerih nastopa climacus z dvojnim nastavkom, kažeta f in a, terca in kvinta finalisa; v modalnosti deuterus (s finalisom e, III. in IV. modus) sta to tona a in cl, ki sta tenorska tona IV. in III. modusa; v modalnosti tritus (s finalisom f, V. in VI. modus) nastopa dvojni climacus pogosto kvarto in kvinto nad finalisom in podobno je v modalnosti tetrardus (s finalisom g, VII. in VIII. modus). Kje se pojavlja climacus z dvojnim nastavkom, je očitno povezano z modalnostjo spevov. Če s temi opažanji primerjamo tone, na katerih se v posameznih modusih pojavljajo climacusi z enojnim nastavkom, vidimo, da nastopajo na ključnih tonih modusov tudi ti, vendar ne tako izrazito; večkrat kot climacuse z dvojnim nastavkom jih moremo v posameznih modusih najti tudi na drugih tonih.

\section{Zaključne ugotovitve}

Kaj je iz predstavljenih opažanj in ugotovitev mogoče razbrati z ozirom na pomen climacusa z dvojnim nastavkom? Kot je pokazala prejšnja razprava, so mesta, kjer se pojavlja dvojni climacus, v določenem smislu neeksaktna, bodisi z ozirom na samo glasbo bodisi z ozirom na notacijski znak. Pregled tonov, kjer se v vsakem modusu pojavlja dvojni climacus, ne odpravlja dvoma o njegovem pomenu niti ne (odpravlja) prikazane neeksaktnosti, vendar jo pojasnjuje: Mesta, kjer se v BNS pojavlja enojni climacus, niso dvomna; njihov zgornji ton ima običajno dolžino. Dvom se pojavlja le v zvezi s climacusom z dvojnim nastavkom, pri katerem bi bil lahko izhodiščni ton spusta (zapisan z dvema punctumoma) na neki način podaljšan ali poudarjen. Kot je bilo prikazano, je prav ta ton zelo pogosto eden od pomembnejših, ključnih tonov modusa in speva, zasnovanega v njem. Zdi se, da so ta mesta ostala nedoločena in neeksaktna prav zato, ker je v resnici obstajal dvom, ali naj se izhodiščni ton climacusa, postavljenega na ključni ton modusa, na neki način izpostavi, podaljša in poudari. S primerom si lahko predstavljamo, da se je pisec rokopisa (ali katere od njegovih neznanih predlog) na neki način moral zavedati razločka med enojnim in dvojnim climacusom, in da je v nekaterih primerih dvomil, ali naj bo izhodiščni ton climacusa poudarjen ali ne; najbrž ni naključje, da je bil v dvomu zlasti takrat, ko je bil prvi ton spusta na katerem od modalno občutljivejšem tonu zapisovanega speva. 


\title{
THE CLIMACUS IN THE BREVIARIUM NOTATUM STRIGONIENSE AND THE GREGORIAN MODALITY
}

\begin{abstract}
Summary
In the notated breviary, known as Breviarium notatum Strigoniense (BNS), which was compiled by the end of the 13th century in the Hungarian ecclesiastical centre Esztergom, there are two forms of climacus (denoting a succession of three or more notes in downward motion): normally, the first note of the sign is given by way of a double punctum (two puncta on the same pitch), beneath which there follow three or more vertically aligned puncta. Sporadically, however, another form of climacus may be found, in which, instead of two, there is just one punctum at the top of the descent. Both varieties function as independent signs, as well as constituent parts of the compound neumes. The notational signs of the BNS are conceived in such a way that they indicate quite clearly the number of respective notes: as in neumatic notation in general, there is also, in the notation of the manuscript under consideration, a clear correspondence between the notes of the melody and their graphic representation, any note of the melody having its graphical equivalent in the respective neumatic sign. This characteristic of the notation implies a prolongation of the first note of the normal form of climacus (with the double punctum). Yet, according to such an interpretation, nearly every succession of three or more notes in downward motion to be found in BNS would start with a prolonged note, which does not seem probable.

In order to determine the precise meaning of the double-punctum climacus in BNS, all the instances of the sign (appearing either independently or in compound neumes, with the first note doubled or not) in the series of 17 advent responsories were copied out and compared to the parallel places in the so called Istanbul antiphoner, which was compiled some decades after the BNS, and was written in the same Hungarian notation (Table 1). The comparison revealed that there is always just a climacus with a single first note at the corresponding places in the younger Istanbul antiphoner (disregarding some unidentifiable cases). From this it would follow that there is no difference in meaning between the two varieties of climacus in the BNS, and that the climacus with the double punctum functions here just as a graphic convention (as was already established by Janka Szendrei). Yet the comparison revealed another interesting aspect of the notation, as well as Gregorian modality: in the BNS the climacus with a double punctum does not appear on all the notes of the gamut equally, but seems to be modally bound, i.e. its first note (written with the double punctum) is to be found especially on the pivotal notes of the modes. This applies to the climacus with the single first note as well, yet not to the same extent (Table 2). From this observation it follows that there is a slight distinction between the two varieties of the sign, and that in the double-first-note climacus the first note might be meant as having a prolonged duration or being emphasised in some other way. However, it seems that the distinction between the two varieties of climacus was not strictly observed by the scribe, who applied the form with the double punctum also for simple downward motion, without any prolongation of the first note.
\end{abstract}

